\title{
RELICT DRAINAGE EFFECTS ON DISTRIBUTION AND MORPHOMETRY OF KARST DEPRESSIONS: A CASE STUDY FROM CENTRAL TAURUS (TURKEY)
}

\author{
Mehmet Furkan Şener ${ }^{1}$, Muhammed Zeynel Öztürk
}

\begin{abstract}
Karst depressions and relict valleys, formed as a result of the combination of karst and fluvial processes, are characteristic landforms of the Taurus karst region in Turkey. Development of these two landforms is interrelated, and the main aim of this study is to explain the role of paleovalley networks on morphometric properties of the depressions. For this purpose, in this study, spatial distribution of karst depressions and relict valleys, and morphometric properties of depressions are investigated on the Ermenek Plateau based on 1:25,000-scaled, topographic maps. About 10,000 karst depressions are mapped, $49.5 \%$ and $50.5 \%$ of them being located in and out of relict valleys, respectively. According to morphometric calculations, there are significant differences in dimensional properties of the two groups of depressions. Mean area, perimeter, short and long axes of relict valley depressions are 2.6, 1.6, 1.6 and 1.4 times larger, respectively, than plateau depressions. Relict valley depressions and plateau depressions are elliptical- and circular-shaped, respectively. Relict valley density has positive effect, while non-relict valley density has negative effect (limiting factor) on spatial distribution of depression density.
\end{abstract}

\section{Introduction}

Karst terrains, in which dissolution by water is the dominant geomorphic process, have distinctive hydrology, surface and subsurface landforms. Large areas of the ice-free continental area of the Earth, especially in the Northern Hemisphere and Mediterranean region, are underlain by karst (Ford and Williams, 2007; De Waele et al., 2009, 2011). Karst terrains cover about $40 \%$ of Turkey, and the largest, most important karst terrain is the Taurus Mountains (Nazik and Poyraz, 2017). Gentle slopes of high karst plateaus are significant morphological units of the Taurus karst region, and these plateaus are highly karstified, also due to effects produced by tectonics (Klimchouk et al., 2006; Monod et al., 2006; Doğan et al., 2017; Doğan and Koçyiğit, 2018). This plateau includes many landforms such as caves, gorges, dry valleys, depressions, ponors and springs, and most of these karst landforms follow structural and orographic lineaments (Elhatip, 1997; Gunn and Günay, 2004; Öztürk et al., 2018b).

Karst depressions (doline, uvala or natural, enclosed depressions) are characteristic landforms of high, karst plateaus in the mid-latitudes and the Taurus karst region in Turkey (Gams, 2000; Öztürk et al., 2018b). Within the neritic limestones, above 2,000 m a.s.l. and low-angle plateaus create appropriate topographic conditions for formation of karst depressions (Gams, 2000; Plan and Decker, 2006; Faivre and Pahernik, 2007; Daura et al., 2014; Öztürk et al., 2015). Dry valleys without surface streams are another characteristic landform of mid-latitude high karst terrains (Warwick, 1964; Parise, 2011; Bočić et al., 2015) and Taurus karst plateaus (Nazik, 1992; Monod et al., 2006; Doğan et al., 2017). Karst valleys are called as dry valley, relict valley, ancient valley, fossil valley, solution valley, paleovalley, paleokarst valley in different studies (Fermor, 1972; Day, 1983; Doğan and Özel, 2005; Sauro, 2013). Originally, these valleys have evolved as normal valleys due to fluvial erosion in the "pre-karst phase" of surface development (Dreybrodt and Gabrovšek, 2003; Košutnik, 2007). Then, the surface drainage started to form an underground drainage network due to joints and fractures, as a result of tectonic uplift (Monod et al., 2006; Bočić et al., 2015). Therefore, the surface drainage network on the karst plateau disappeared and turned into a network of dry valleys (Bočić, 2003). Later on, it was gradually replaced by solution depressions as a result of karstification (Doğan and Özel, 2005; Bočić et al., 2015; Petrovic et al., 2016). The bottoms of these valleys are covered with elongated depressions and conical, residual hills (Monod et al., 2006; Ford and Williams, 2007; Radulović, 2013). The depressions form the most important connections between surface and underground drainage systems (Sauro, 2012). Besides, underground channels and speleological objects can be present under dry valleys (Bočić, 2003). These processes were called "reorganization of drainage by karstification" by Williams (1982).

Although karst plateaus are a variant of the fluvial, geomorphological system (Ford et al., 1988), these plateaus are characterized by a lack of surface drainage. As a result, solution depressions and relict valleys have been formed by a combination of karst and fluvial processes (Košutnik, 2007; Sauro, 2013); the development of these two landforms is strictly related (Day, 1983; Segura et al., 2007). In this study, the spatial distribution of karst depressions and relict valleys, and the effects of relict valleys on depression morphometry are investigated on the Ermenek Plateau, based on GIS tools. The main aims of this study are: (1) to determine the spatial distribution of karst depressions with respect

'Department of Geography, Faculty of Arts and Sciences, Niğde Ömer Halisdemir University, Nigde, Turkey

*Corresponding Author: muhammed.zeynel@gmail.com 
to relict and non-relict valleys; (2) to explain the relationships between spatial distributions of these; and (3) to explain the effects of a relict valley on morphometric properties of depressions.

\section{Study Area}

The Ermenek Plateau is one of the most characteristic plateaus of the Taurus Mountains, which form a continuous karst belt across the southern part of Turkey; the study area covers $1,584 \mathrm{~km}^{2}$ of the plateau surface (Fig. 1). Mean elevation of study area is $1,707 \mathrm{~m}$ a.s.l., and there are many summits over $2,000 \mathrm{~m}$ a.s.l. at the northern part of the area. The plateau surface is eroded by many rivers (Oğuzun, Balkusan, Akerik and Günder rivers), which run in a NW-SE direction, therefore, parallel to the Göksu River (Fig. 1c). These rivers have incised more than $100 \mathrm{~m}$ and the slopes are more than $30^{\circ}$ steep. For example, the Balkusan River, located on the southern part of the plateau, incised ca. 300
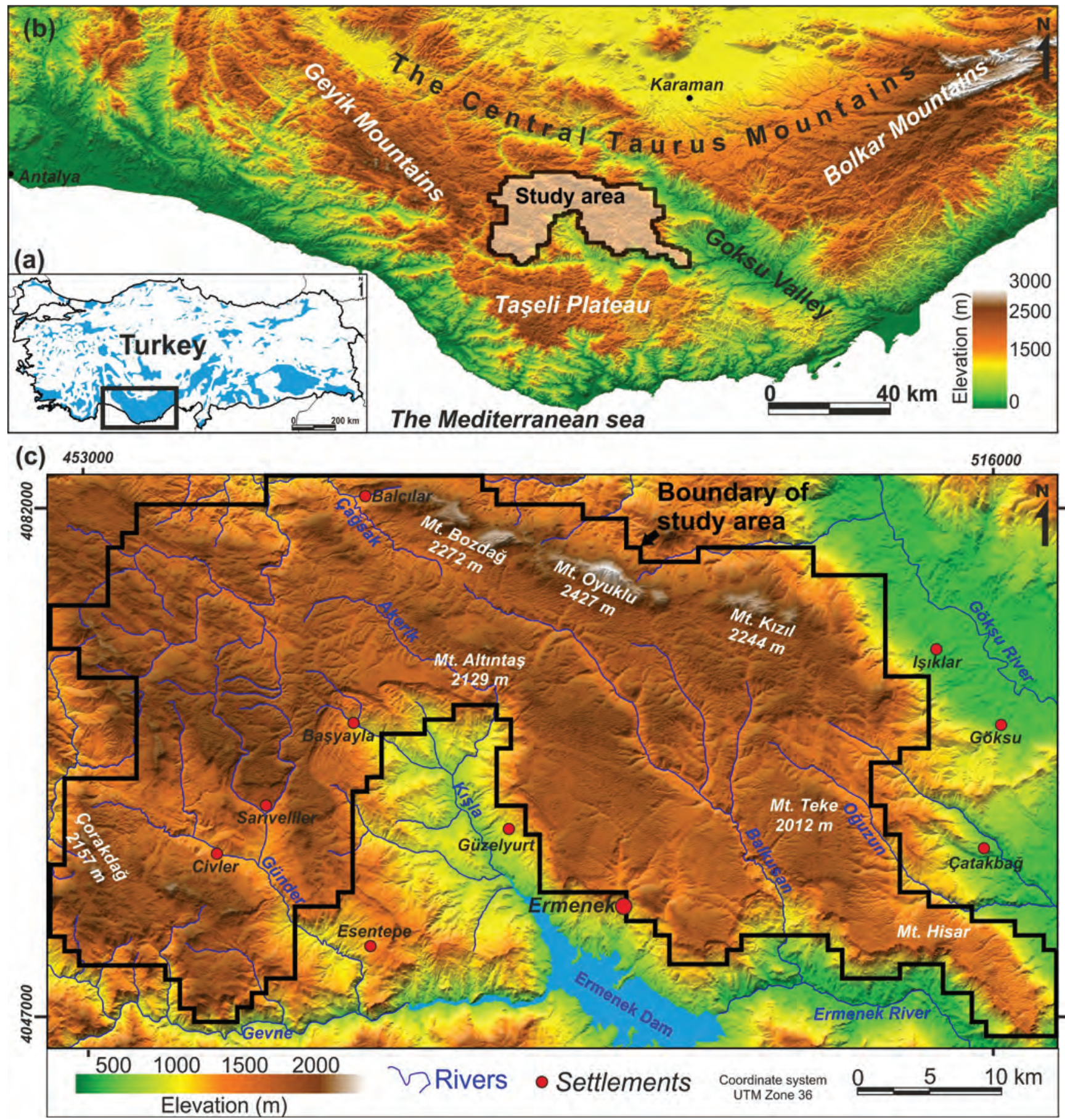

Figure 1. (a) Outcrops of carbonate rocks in Turkey (Nazik and Tuncer, 2010), (b) the Central Taurus Mountains and location of the study area, (c) digital elevation model of study area (black line shows boundary of study area). 
$\mathrm{m}$ and the river side slopes are up to $50^{\circ}$ steep. The eastern and southern boundaries of plateaus are limited by steep slopes (Fig. 3a). According to the Ermenek Meteorology Station (at 1,267 m a.s.I.), the mean annual temperature is $11.6^{\circ} \mathrm{C}$, and mean annual precipitation is $667 \mathrm{~mm}$.

The study area mostly consists of neritic limestones, carbonates, and clastic rocks that were deposited in Mut-Ermenek Basin (Fig. 2, 3). This basin is one of several, small Cenozoic basins in the southern part of Turkey (Şafak et al., 2005; Janson et al., 2010). The basin was formed as a result of orogeny collapse in the extensional back arc regime of the Cyprus arc to the south (Robertson, 2000). The basin was inundated by the sea in the Early Miocene, and jointly covered with an extensive, thick succession of late Burdigalian to Serravalian carbonates, including reef and platform limestones. The NW-SE, NE-SW, and E-W directed fault systems developed in basins that are related to the orogenic collapse (Esirtgen et al., 2016). The study area is mainly comprised of the Burdigalian-Serevalian limestones in the Ermenek Basin, represented by the Mut Formation (Gedik et al., 1979). This consists of limestones, but also contains sandstone, conglomerate, and marl bands. The white, cream-colored limestones contain micro and macro fossils, such as algae, foraminifera, echinid, lamellibranch, gastropod and coral (Özkale et al., 2007). The reef limestones are characterized by organisms of warm, clear and shallow marine environments. Besides, NW-SE, NE-SW, and E-W-directed fault systems cut the Miocene marine sequences, as well (Esirtgen et al., 2016).

\section{Method}

Morphometric analysis of karst landforms is a useful tool for evaluation of karst areas (Jennings, 1975; Day, 1983; Bondesan et al., 1992; Bruno et al., 2008; Basso et al., 2013; Öztürk et al., 2017, 2018a). These morphometric analyses enable us to develop a hypotheses on the evolution and dynamics of karst systems (Jeanpert et al., 2016), and to classify karst landforms (Aguilar et al., 2016). In this study, morphometric properties of karst depressions in relict valleys and on the pla-

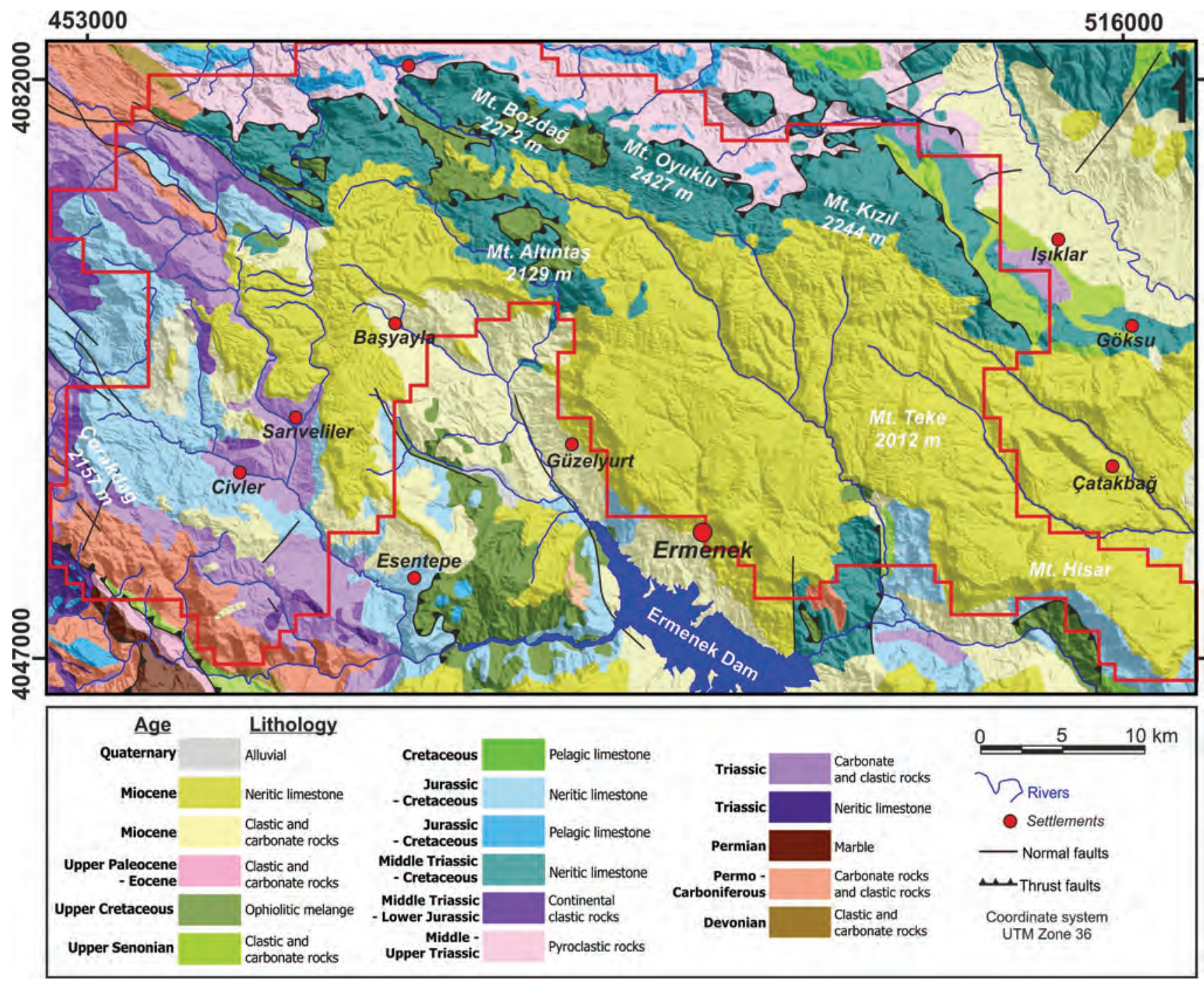

Figure 2. Geological map of study area (arranged from Şenel, 2002a, 2002b. Red line shows boundary of study area). 

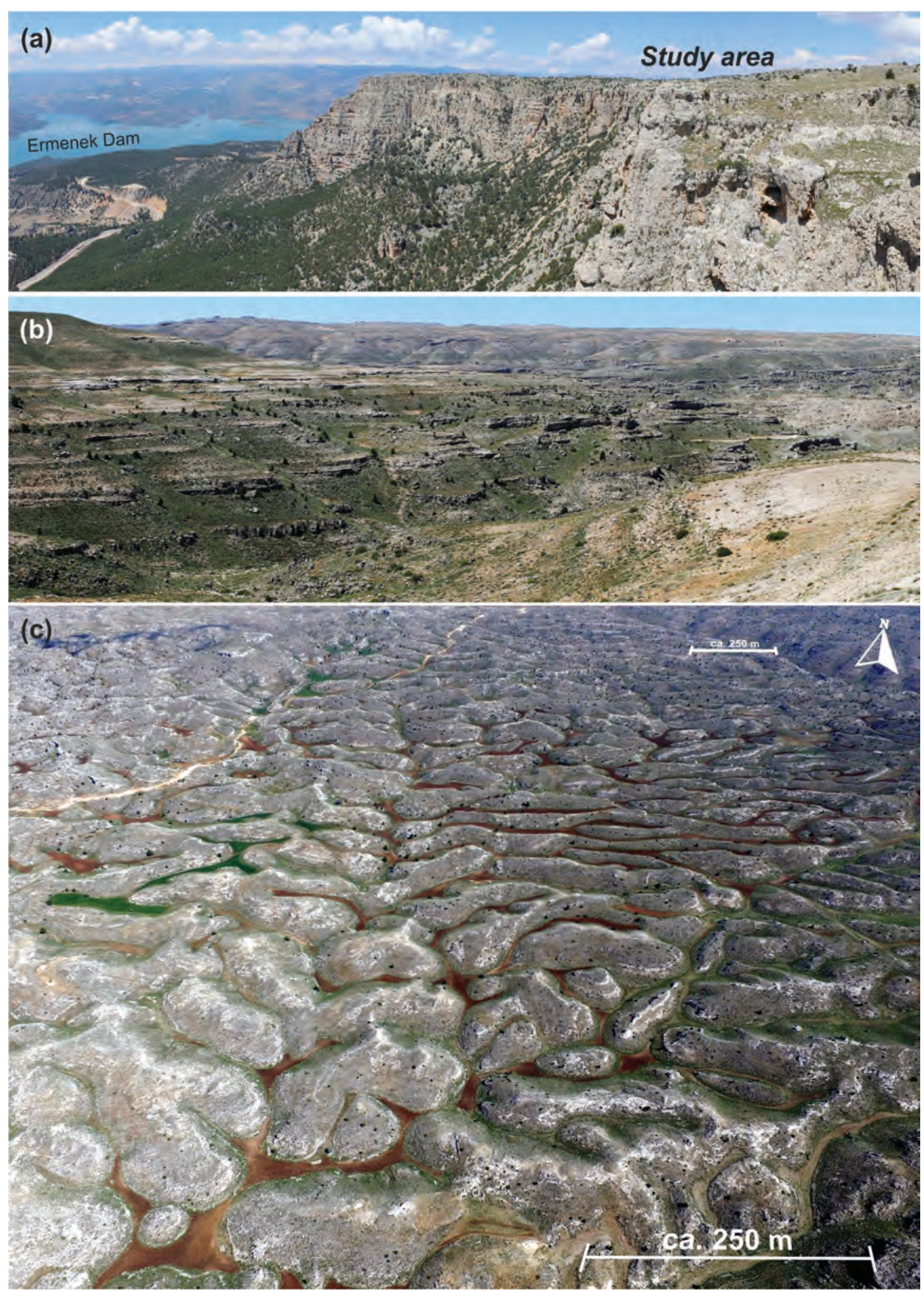

Figure 3. (a) Steep slopes at the southern parts of the plateaus, (b) the Miocene neritic limestone layers and (c) drone image of plateau surface. teau surface (outside of relict valleys) are investigated. Topographic maps (UTM zone 36), 1:25,000-scale, produced by The General Command of Mapping (Turkey), were used to determine the distribution of karst depressions, relict and non-relict valleys on the plateau (Day, 1983; Denizman, 2003; Applegate, 2003; Angel et al., 2004; Florea, 2005; Faivre and Pahernik, 2007; Telbisz et al., 2009; Benac et al., 2013; Bočić et al., 2015; Keskin and Yllmaz, 2016; lovine et al., 2016; Margiotta et al., 2016; Parise et al., 2018). The uppermost, closed-contour lines of karst depressions on topographic maps (classical method) were delineated as polygons in a GIS, and basic morphometric properties (area, perimeter, long axis, short axis, elongation ratio and circularity index) were calculated. Elevation values of the depression were determined from topographic maps, with reference to uppermost, closed-counter values.

The long axis (a line connecting the two farthest points) and short axis of depressions were drawn manually. Depressions are used as a sensitive indicator for tectonic activity in a karst region, and azimuth orientation of the doline long axes provides important clues about their joint systems (Day, 1983; Nazik, 1986; Pardo-Igúzquiza et al., 2013; Pepe and Parise, 2014; Jeanpert et al., 2016; Öztürk et al., 2017, 2018a). Therefore, the orientation angles of depressions were calculated as an azimuth of the long axis within the depression, and rose diagrams were created for the two depression groups. 
The drainage network was divided into two categories: relict and non-relict valleys. Relict valleys developed due to karst denudation processes from the primary valley morphology (Bočić et al., 2015). Other valleys are recognized as non-relict valleys. In other words, if the valleys have depressions at their thalwegs, they are classified as relict, otherwise as non-relict valleys. Relict and non-relict valleys were determined by vectorization of the theoretical thalwegs (Bočić et al., 2015). Then, the depressions, which are located in and outside of relict valleys, were determined using GIS analyses (Fig. 4). The data sets were examined in $1 \mathrm{~km} \times 1 \mathrm{~km}$ quadrants to determine spatial densities of depression, relict and non-relict valleys, and the relationships between them (Pahernik, 2012; Bočić et al., 2015). Besides, minimum, $5 \%, 25 \%$, average, $75 \%, 95 \%$ and maximum values are calculated for evaluation of morphometric elevation characteristics of depressions (Öztürk et al., 2018b).

\section{Results}

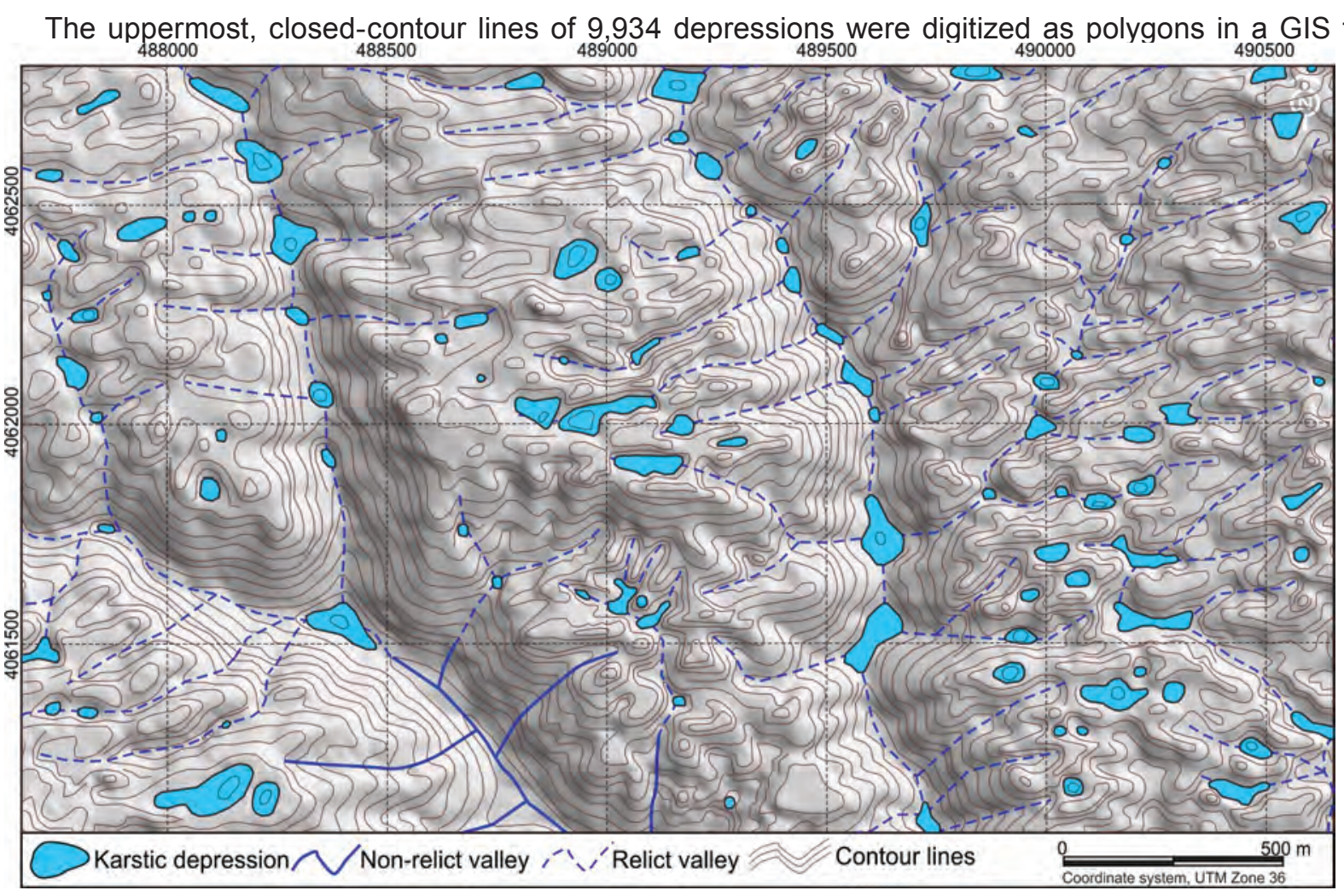

Figure 4. Examples of relict and non-relict valleys (contour interval is $10 \mathrm{~m}$ ).

with maximum depression density of 75

depressions $/ \mathrm{km}^{2}$ between these elevations. According to classification of depression density by Faivre and Pahernik (2007), $65.1 \%$ of the study area is characterized by low density ( $<10$ depressions $/ \mathrm{km}^{2}$ ), $33.4 \%$ with moderate density (10-40 depressions $\left./ \mathrm{km}^{2}\right), 0.34 \%$ with high density (40-70 depressions $/ \mathrm{km}^{2}$ ) and only $0.03 \%$ with very high density ( $>70$ depressions $/ \mathrm{km}^{2}$; Fig. 5). Spatial distribution of depression density is parallel to the main river direction, due to plateau surface being eroded by rivers in the NW-SE direction. Depression density increases with distance from the main rivers (Fig. 5).

Relict valley density increases at the central parts of the plateau. It is greater than three $\mathrm{km} / \mathrm{km}^{2}$ over $1,150 \mathrm{~m}$ a.s.l., with maximum density $\left(8.5 \mathrm{~km} / \mathrm{km}^{2}\right)$ between 1,750 and $1,900 \mathrm{~m}$ a.s.I. Non-relict valley density reaches $11 \mathrm{~km} / \mathrm{km}^{2}$ on the plateau surface, and a negative correlation is observed between the distribution of relict and non-relict valley densities ( $r=-65$ : Fig. 6a, c).

Relict and non-relict drainage density has two effects on the distribution of depression density: While relict drainage density has a positive effect, non-relict drainage density has a negative effect (limiting factor) on the spatial distribution of depression density. A positive correlation is observed between depression density and relict drainage density $(r=$ $0.6)$, while a negative correlation $(r=-0.5)$ is observed between depression density and non-relict drainage density (Fig. 6b, d).

Solution depressions can be found both on the plateau surface (or on interfluve) and in the relict valleys. Thus, depressions are divided into two groups: (1) relict valley depressions and (2) plateau surface depression in this study. Inside and outside of relict valleys, 4,917 (49.5\%) and 5,017 (50.5\%) depressions are located, respectively. These per- 


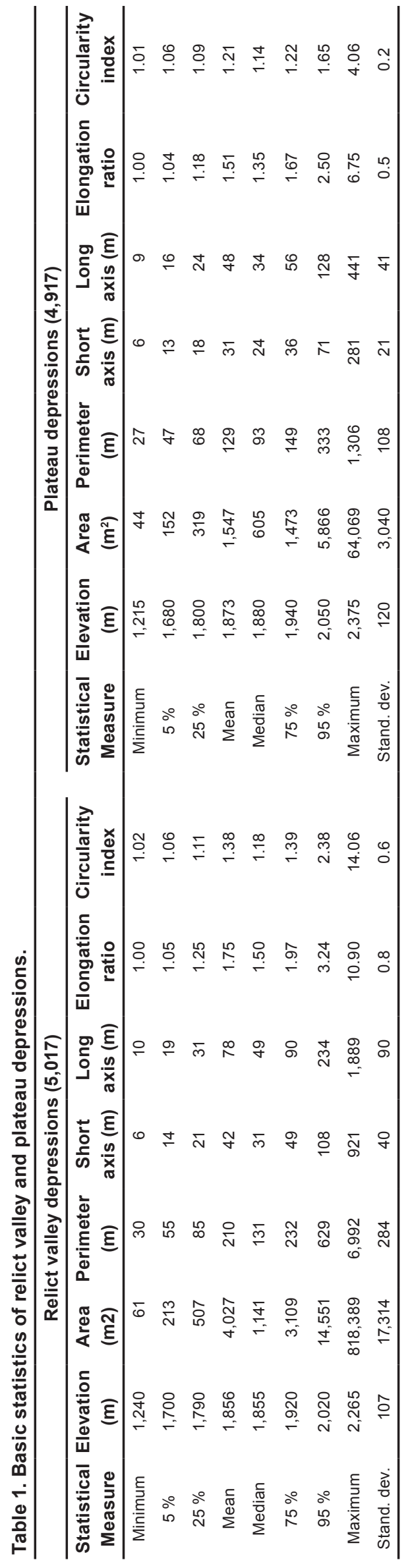

centages provide perfect conditions for statistical analysis of the morphometric properties of the two depression groups.

There is no significant difference in the distribution, while there are significant differences in the dimensional properties of the two groups. The minimum values of the two groups are similar. Strong, positive correlations are observed between perimeter and area, short and long axes, elongation ratio and circularity index in the two groups. Generally, the values are larger for the relict valley depressions than for the plateau depressions: mean area by 2.6 , perimeter by 1.6 , short axes by 1.6 and long axes by 1.4 times. Standard deviations of the relict valley depressions are higher than for those of the plateau depressions (Table 1). As a result, relict valley depressions and plateau depressions are elliptical and circular-shaped, respectively (Fig. 8a and d). These differences resulted from the enlargements of the relict valley depressions. Besides, solution pits and conical or tower- shaped residual hills are observed in relict valley depressions (Figs. $8 b$ and $c)$.

The long axes orientations of the depression are used as an indicator for the direction of tectonic structures, and these orientations provide important clues about the fracture systems (Pepe and Parise. As shown in Figure 9, dominant directions are ENE-WSW and WNW-ESE for both depression types, which are in accordance with the tectonic evolution of the study area.

These results indicate that relict valley density is one of the most important factors to determine the spatial distribution of depression density on the Ermenek Plateau. Depression density reaches its maximum in a well-developed, relict-valley network on the neritic limestones. The relict valley depressions are more elongated, whilst the plateau depressions are more circular.

\section{Discussion}

Dry valley and karst depressions have been investigated for a long time (Reid, 1887; Warwick, 1964; Fermor, 1972; Day, 1983; Jennings, 1982), due to their important role in interpretation of morphotectonic development of karst surfaces, as well as their hydrological role in response to rainfall (Parise, 2003). Especially, relict and dry valleys are used for paleodrainage reconstructions (Bočić, 2003; Monod et al., 2006; Petrovic et al., 2016; Doğan et al., 2017), and a few studies explain the relationship between both (Williams, 1972; Jennings, 1975; Bočić et al., 2015).

In this study, the spatial distribution of karst depressions and relict valleys, and the effects of relict valley depression morphometry are investigated on the Ermenek Plateau. Non-relict valley density is a limiting factor for depression density. When non-relict valley density increases, depression densities decline (Fermor, 1972; Öztürk et al., 2017). Because of this correlation, depression density is greatest at maximum distances from non-relict valleys. 


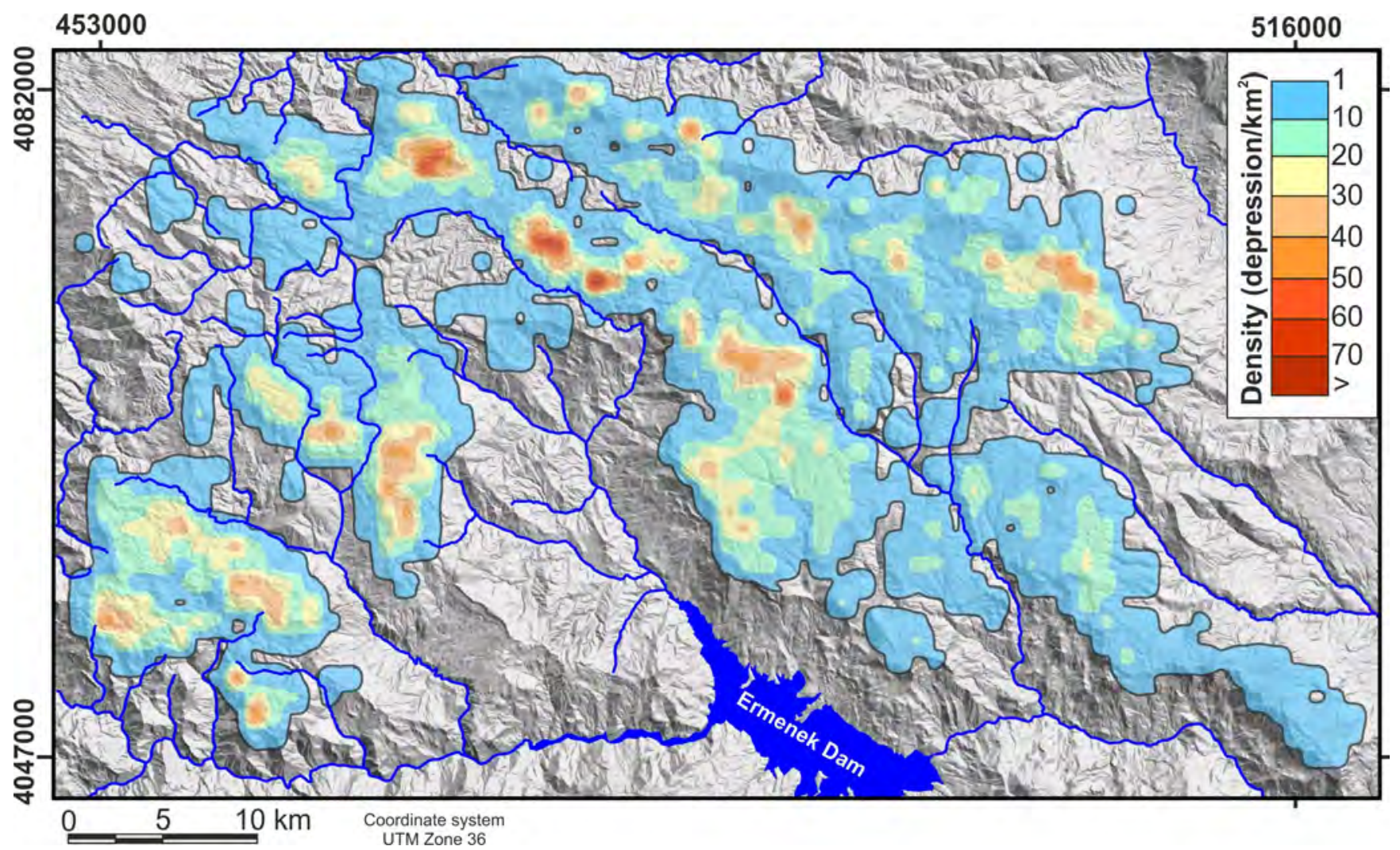

Figure 5. Spatial distribution of depression density.
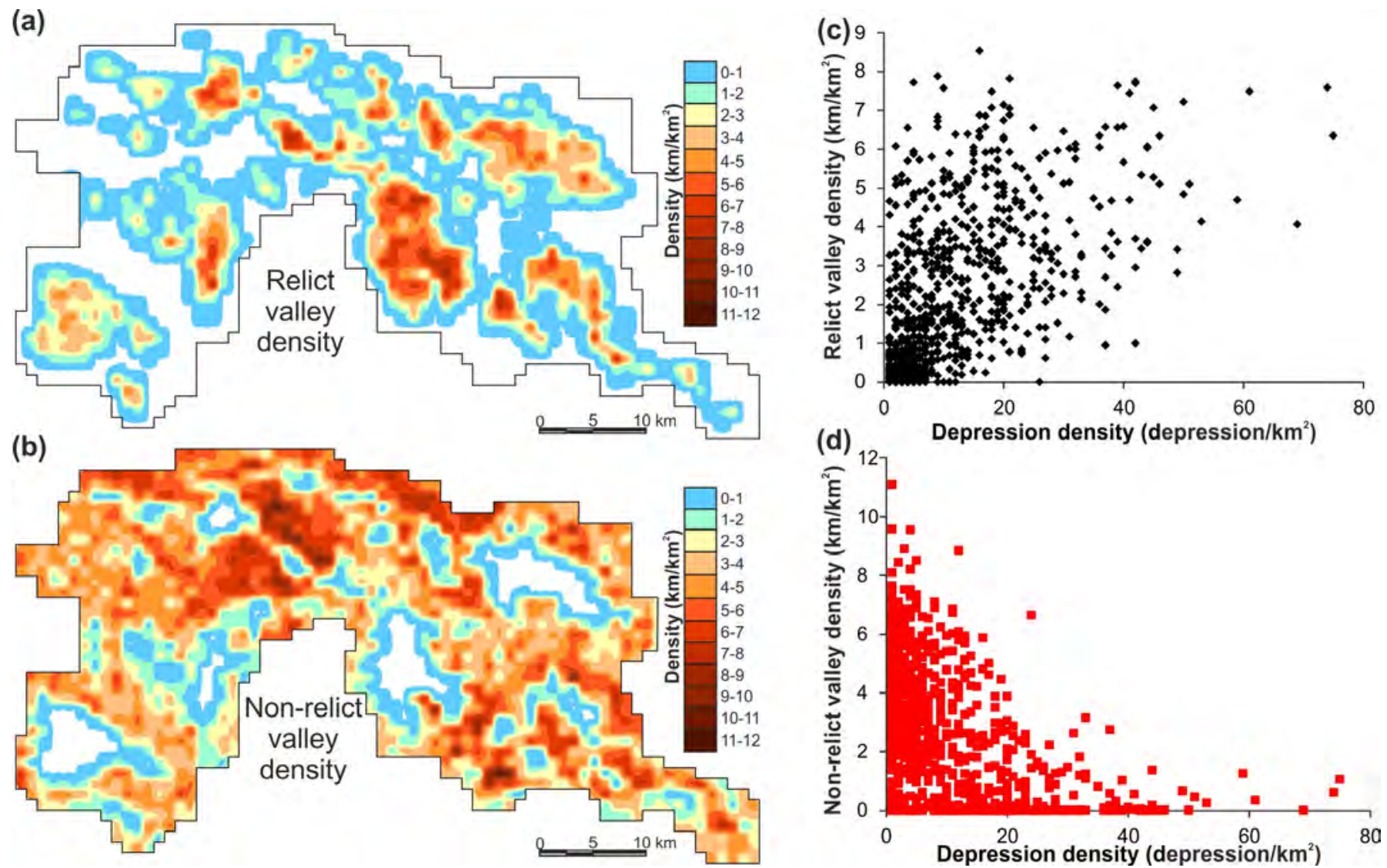

Figure 6. Spatial distribution of (a) relict valley density, (b) correlations between depression density and relict valley density, (c) non-relict valley density and (d) correlations between depression density and non-relict valley density. 

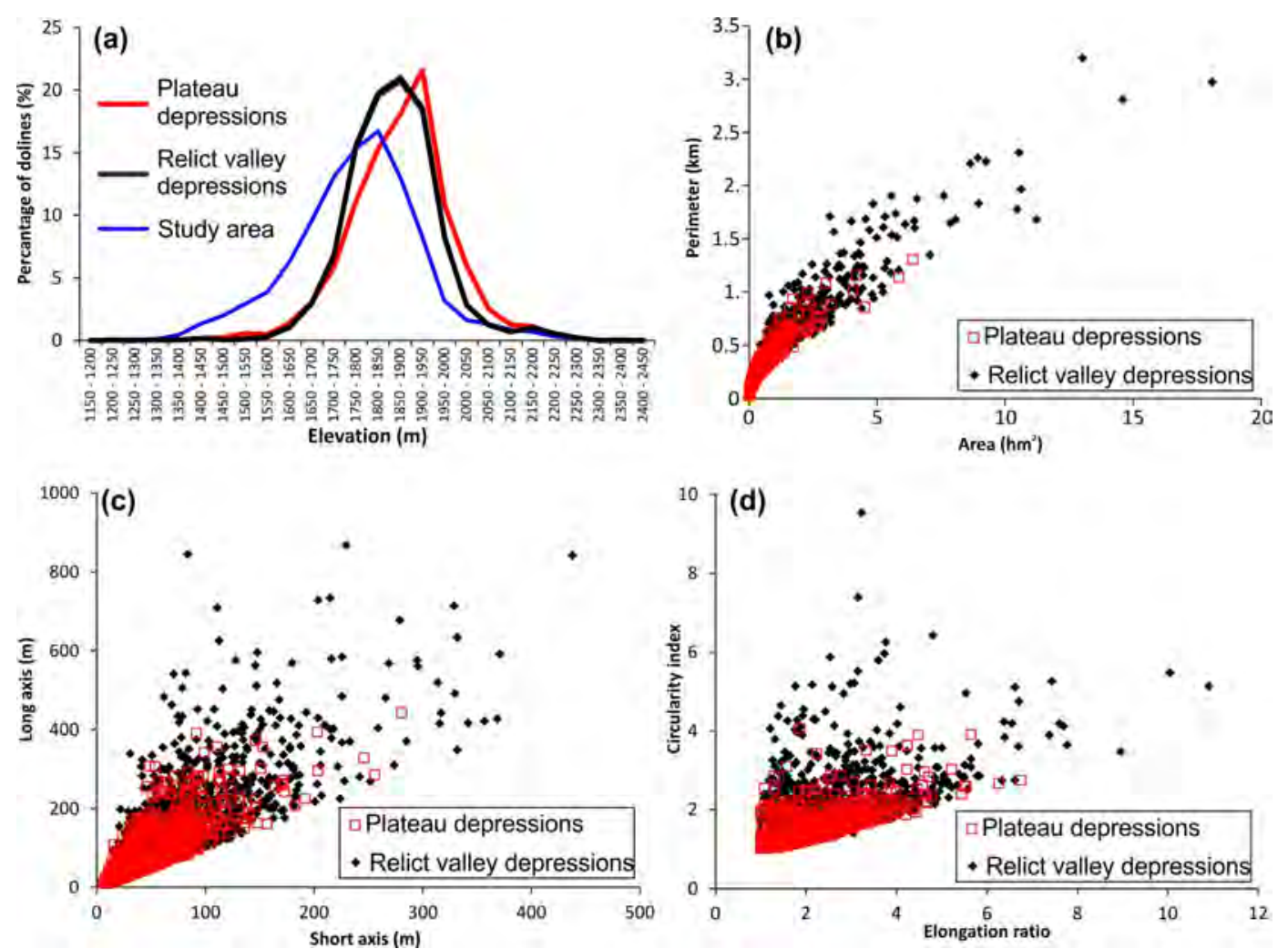

Figure 7. (a) Change of depression elevation and relationships between (b) perimeter and area, (c) long and short axis, (d) circularity index and elongation ratios (maximum values of relict valley depressions are not shown in figure $7 \mathrm{~b})$.
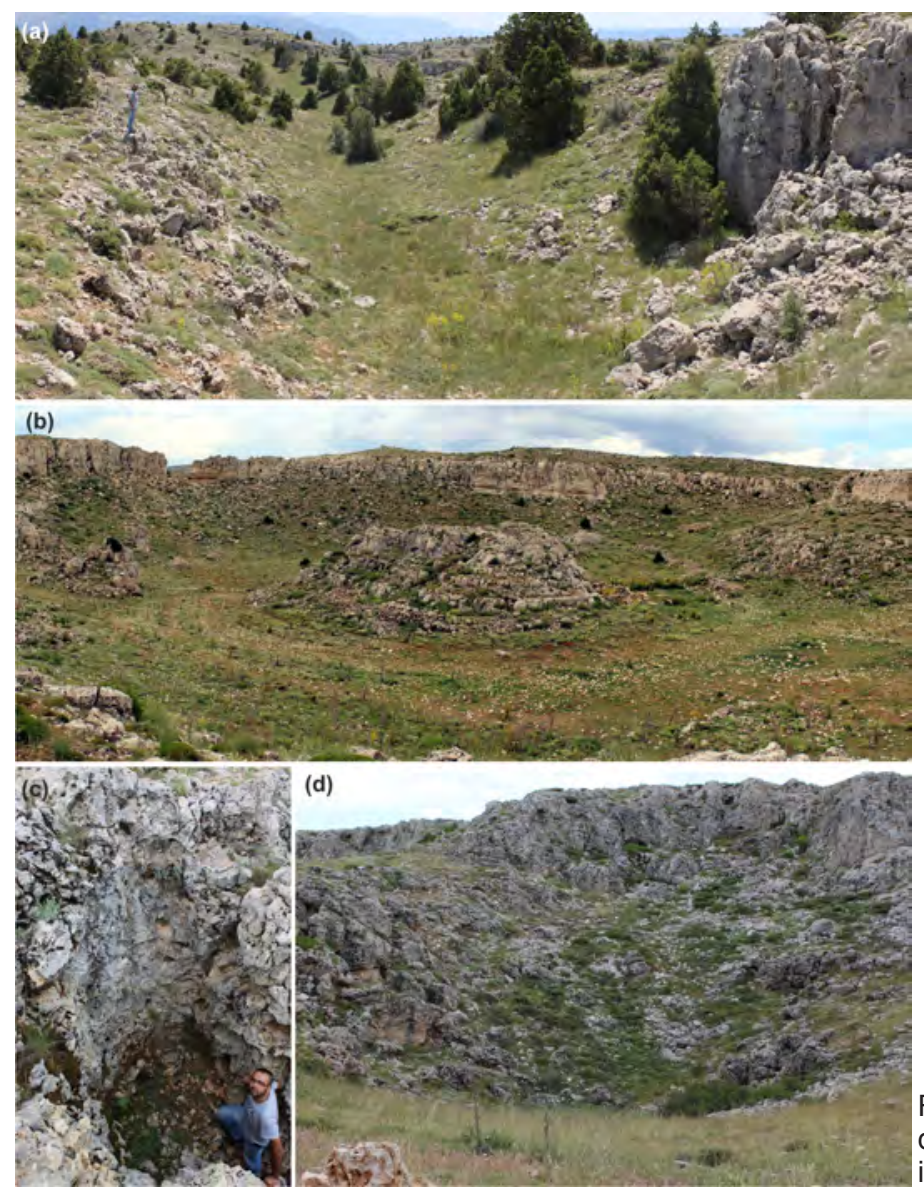

Figure 8. Depressions types on plateau: (a) elongated relict valley depression, (b) residual hill in relict valley depression, (c) solution pit in relict valley depression and (d) circular plateau depression. 
(a) Relict valley depressions

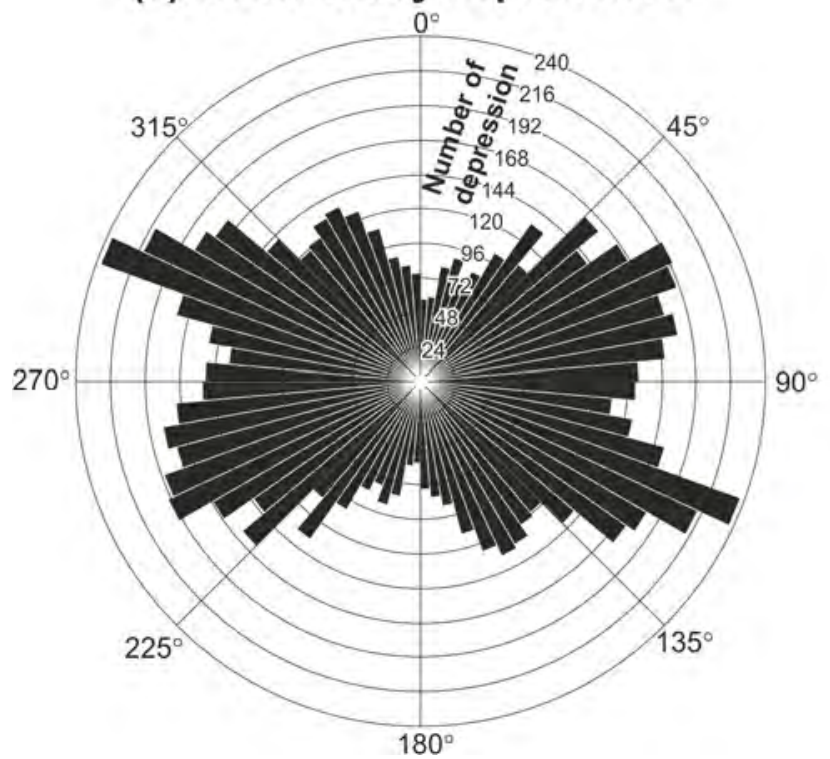

(b) Plateau depressions

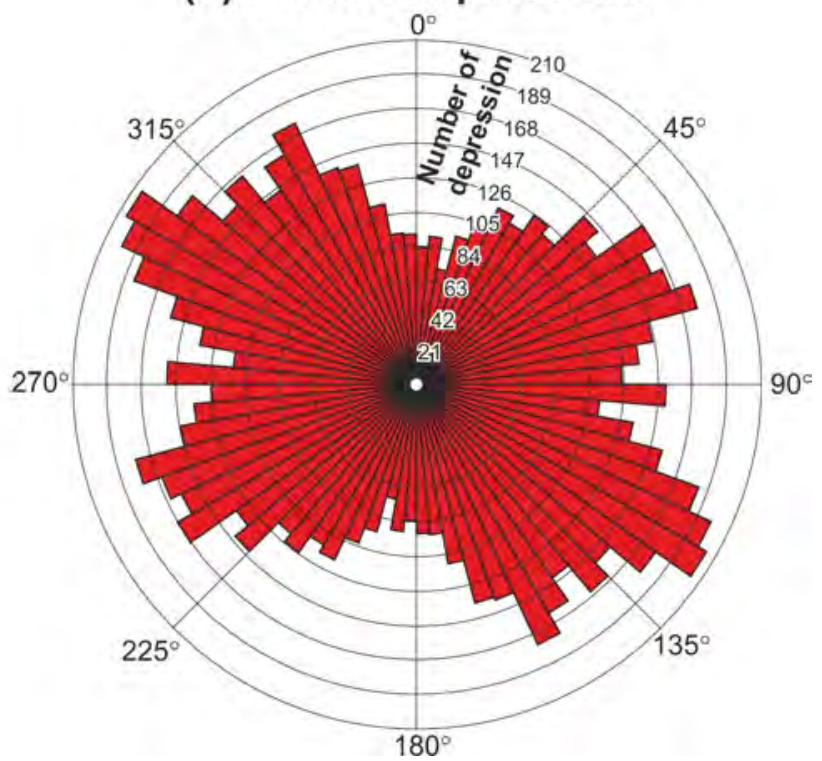

Figure 9. Rose diagrams for the long axis of (a) relict valley depressions and (b) plateau depression.

Statistically, relict valley depressions have complex shape and larger area than plateau depressions. Similarly, length, width and depth of valley depressions are greater than plateau depressions in New Zealand (Jennings, 1975). This situation results from hydrological properties of the two groups. Since karst depression is a hydrological form (Sauro, 2012) and each depression has its own catchment area (drainage basin) (Gunn, 1981; Ford and Williams, 2007). Thus, closed-solution depressions have the same function in karst landscapes as valley depressions in fluvial landscapes (Williams, 1972; Gutiérrez et al., 2014). While relict valley depressions have large basins, and they can be found to join points of more than one paleovalley tributary and joint system. Plateau depressions have small basins. In other words, while plateau depressions located at low paleovalley order (generally one), relict valley depressions have high paleovalley order (Day, 1983). Thus, valley depressions are exposed to accelerated solution. Most of the water of the valley slopes is conveyed in the lower part of the depression, in contrast to plateau depressions (Sauro, 2013). As a result, depressions in relict valleys start to enlarge and lose to circular shape (Doğan and Özel, 2005).

\section{Conclusions}

In this study, the spatial distribution of karst depressions and relict valleys, and relict valley effects on depression morphometry are investigated on the Ermenek Plateau, based on 1:25,000-scaled topographic maps. Depressions totaling 9,934 were mapped. Out of these, 4,917 and 5,017 depressions are located inside and outside of relict valleys, respectively. Mean area, perimeter, short and long axes of relict valley depressions are significantly larger than the plateau depressions. Besides, standard deviations of relict valley depressions are higher than plateau depressions. As a result, while relict valley depressions are elongated, plateau depressions are circular in shape. These situations result from hydrological differences between two depression groups. Relict drainage density has positive effects, while non-relict drainage density has negative effects (limiting factors) on spatial distribution of depression density. Dominant orientations of both depressions are ENE-WSW and WNW-ESE, and these orientations are in harmony with tectonic directions of the study area. According to these results, both landforms are impressed by the same tectonic evolution, and geomorphologic development of depressions are associated with paleodrainage patterns.

\section{Acknowledgements}

This study was supported by the Scientific and Technological Research Council of Turkey (TUBITAK) (Project no: 115Y580). We express our sincere thanks for their financial support. We also thank to Dr. Mesut Şimşek and Mustafa Utlu.

\section{References}

Aguilar, Y., Bautista, F., Mendoza, M.E., Frausto, O., and Ihl, T., 2016, Density of karst depressions in Yucatán state, Mexico: Journal of Cave and Karst Studies, v. 78, p. 51-60. https://doi.org/10.4311/2015ES0124.

Angel, J.C., Nelson, D.O., and Panno, S.V., 2004, Comparison of a new GIS-based technique and a manual method for determining sinkhole density: An example from Illinois' sinkhole plain: Journal of Cave and Karst Studies, v. 66, p. 9-17. 
Applegate, P., 2003, Detection of sinkholes developed on shaly Ordovician limestones, Hamilton County, Ohio, using digital topographic data: Dependence of topographic expression of sinkholes on scale, contour interval, and slope: Journal of Cave and Karst Studies, v. 65, p. 126-129. https://caves.org/pub/journal/PDF/V65/v65n2-Applegate.pdf.

Basso, A., Bruno, E., Parise, M., and Pepe, M., 2013, Morphometric analysis of sinkholes in a karst coastal area of southern Apulia (Italy): Environmental Earth Sciences, v. 70, p. 2545-2559. https://doi.org/10.1007/s12665-013-2297-z.

Benac, Č., Juračić, M., Matičec, D., Ružić, I., and Pikelj, K., 2013, Fluviokarst and classical karst: Examples from the Dinarics (Krk Island, Northern Adriatic, Croatia): Geomorphology, v. 184, p. 64-73. https://doi: 10.1016/j.geomorph.2012.11.016.

Bočić, N., 2003, Relation between Karst and Fluviokarst Relief on the Slunj Plateau (Croatia): Acta Carsologica, v. 32. https://doi.org/10.3986/ AC.V3212.343.

Bočić, N., Pahernik, M., and Mihevc, A., 2015, Geomorphological significance of the palaeodrainage network on a karst plateau: The Una-Korana plateau, Dinaric karst, Croatia: Geomorphology, v. 247, p. 55-65. https://doi/10.1016/J.GEOMORPH.2015.01.028.

Bondesan, A., Meneghel, M., and Sauro, U., 1992, Morphometric analysis of dolines: International Journal of Speleology, v. 21.

Bruno, E., Calcaterra, D., and Parise, M., 2008, Development and morphometry of sinkholes in coastal plains of Apulia, southern Italy. Preliminary sinkhole susceptibility assessment: Engineering Geology, v. 99, p. 198-209. https://doi.org/10.1016/j.enggeo.2007.11.017.

Daura, J., Sanz, M., Josep Forn S.J., Asensio, A., and Julia, R., 2014, Karst evolution of the Garraf Massif (Barcelona, Spain): doline formation, chronology and archaeo -palaeontological archives: Journal of Cave and Karst Studies, v. 76, p. 69-87. https://doi.org/10.4311/2011ES0254.

Day, M., 1983, Doline morphology and development in Barbados: Annals of the Association of American Geographers, v. 73, p. 206-219. https:// doi.org/10.1111/j.1467-8306.1983.tb01408.x.

De Waele, J., Gutiérrez, F., Parise, M., and Plan, L., 2011, Geomorphology and natural hazards in karst areas: A review: Geomorphology, v. 134, p. 1-8. https://doi.org/10.1016/j.geomorph.2011.08.001.

De Waele, J., Plan, L., and Audra, P., 2009, Recent developments in surface and subsurface karst geomorphology: An introduction: Geomorphology, v. 106, p. 1-8. htps://doi.org/10.1016/j.geomorph.2008.09.023.

Denizman, C., 2003, Morphometric and spatial distribution parameters of karstic depressions, Lower Suwannee River Basin, Florida: Journal of Cave and Karst Studies, v. 65, p. 29-35.

Doğan, U., and Koçyiğit, A., 2018, Morphotectonic evolution of Maviboğaz canyon and Suğla polje, SW central Anatolia, Turkey: Geomorphology, v. 306, p. 13-27. https://doi.org/10.1016/j.geomorph.2018.01.001.

Doğan, U., Koçyiğit, A., and Gökkaya, E., 2017, Development of the Kembos and Eynif structural poljes: Morphotectonic evolution of the Upper Manavgat River basin, central Taurides, Turkey: Geomorphology, v. 278, p. 105-120. https://doi.org/10.1016/j.geomorph.2016.10.030.

Doğan, U., and Özel, S., 2005, Gypsum karst and its evolution east of Hafik (Sivas, Turkey): Geomorphology, v. 71, p. 373-388. https://doi. org/10.1016/j.geomorph.2005.04.009.

Dreybrodt, W., and Gabrovšek, F., 2003, Basic processes and mechanisms governing the evolution of karst: Speleogenesis and Evolution of Karst Aquifers, v. 1, p. 1-25.

Elhatip, H., 1997, The influence of karst features on environmental studies in Turkey: Environmental Geology, v. 31, p. 27-33. https://doi. org/10.1007/s002540050160.

Esirtgen, T., Ilgar, A., Bozkurt, B., and Demirkaya, S., 2016, Structural development of Oligo-Miocene basıns in Central Taurides, in 69th Geological Congress of Turkey, Ankara, p. 8-9.

Faivre, S., and Pahernik, M., 2007, Structural influences on the spatial distribution of dolines, Island of Brač, Croatia: Zeitschrift für Geomorphologie, v. 51, p. 487-503. https://doi.org/10.1127/0372-8854/2007/0051-0487.

Fermor, J., 1972, The dry valleys of Barbados: A critical review of their pattern and origin: Transactions of the Institute of British Geographers, p. 153-165. https://doi.org/10.2307/621559.

Florea, L., 2005, Using state-wide GIS data to identify the coincidence between sinkholes and geologic structure: Journal of Cave and Karst Studies, v. 67, p. 120-124.

Ford, D.C., Palmer, A.N., and White, W.B., 1988, Landform development; karst, in Back, W., Rosenshein, J.S., and Seaber, P.R., eds., Hydrogeology (The geology of North America), Geological Society of America, p. 401-412.

Ford, D., and Williams, P., 2007, Karst Hydrogeology and Geomorphology: West Sussex, England, John Wiley \& Sons Ltd. https://doi. org/10.1002/9781118684986.

Gams, I., 2000, Doline morphogenetic processes from global and local viewpoints: Acta Carsologica, v. 29, p. $123-138$.

Gedik, A., Birgili, Ş., Yılmaz, H., and Yoldaş, R., 1979, Mut-Ermenek-Silifke yöresinin jeolojisi ve petrol olanakları: Bulletin of the Geological Society of Turkey, v. 22, p. 7-26.

Gunn, J., 1981, Hydrological processes in karst depressions: Z. Geomorph., (N. F.), v. 25, p. 313-331.

Gunn, J., and Günay, G., 2004, Turkey, in Gunn, J., ed., Encyclopedia of Caves and Karst Science, Taylor and Francis Group, p. $1583-1589$. https://doi.org/10.4324/9780203483855.

Gutiérrez, F., Parise, M., De Waele, J., and Jourde, H., 2014, A review on natural and human-induced geohazards and impacts in karst: Earth-Science Reviews, v. 138, p. 61-88. https://doi.org/10.1016/j.earscirev.2014.08.002.

lovine, G., Vennari, C., Gariano, S.L., Caloiero, T., Lanza, G., Nicolino, N., Suriano, S., Ferraro, G., and Parise, M., 2016, The "Piano dell'Acqua" sinkholes (San Basile, Northern Calabria, Italy): Bulletin of Engineering Geology and the Environment, v. 75 , p. 37-52. https://doi.org/10.1007/ s10064-015-0737-6.

Janson, X., Van Buchem, F.S.P., Dromart, G., Eichenseer, H.T., Dellamonica, X., Boichard, R., Bonnaffe, F., and Eberli, G., 2010, Architecture and facies differentiation within a Middle Miocene carbonate platform, Ermenek, Mut Basin, southern Turkey: Geological Society, London, Special Publications, v. 329, p. 265-290. https://doi.org/10.1144/SP329.11.

Jeanpert, J., Genthon, P., Maurizot, P., Folio, J.-L., Vendé-Leclerc, M., Sérino, J., Join, J.-L., and Iseppi, M., 2016, Morphology and distribution of dolines on ultramafic rocks from airborne LiDAR data: the case of southern Grande Terre in New Caledonia (SW Pacific): Earth Surface Processes and Landforms, v. 41, p. 1854-1868. https://doi.org/10.1002/esp.3952.

Jennings, J.N., 1975, Doline morphometry as a morphogenetic tool: New Zealand examples: New Zealand Geographer, v. 31, p. 6-28. https:// doi.org/10.1111/j.1745-7939.1975.tb00793.x.

Jennings, J.N., 1982, Quaternary complications in fluviokarst at Cooleman Plain, N.S.W.: Australian Geographer, v. 15, p. 137-147. https://doi. org/10.1080/00049188208702809.

Keskin, I., and Yılmaz, I., 2016, Morphometric and geological features of karstic depressions in gypsum (Sivas, Turkey): Environmental Earth Sciences, v. 75, p. 1040. https://doi.org/10.1007/s12665-016-5845-5. 
Klimchouk, A., Bayari, S., Nazik, L., and Törk, K., 2006, Glacial destruction of cave systems in high mountains, with a special reference to the Aladaglar massif, Central Taurus, Turkey: Acta Carsologica, v. 35, p. 111-121, http://carsologica.zrc-sazu.si/downloads/352/klimchouk.pdf (accessed September 2017).

Košutnik, U.J., 2007, Questions of dry valleys in karst: Case study of Mali dol, Kras (Slovenia): Acta Carsologica, v. 36, p. 425-431. https://doi. org/10.3986/ac.v36i3.176.

Margiotta, S., Negri, S., Parise, M., and Quarta, T.A.M., 2016, Karst geosites at risk of collapse: the sinkholes at Nociglia (Apulia, SE Italy): Environmental Earth Sciences, v. 75, p. 8. https://doi.org/10.1007/s12665-015-4848-y.

Monod, O., Kuzucuoglu, C., and Okay, A., 2006, A Miocene palaeovalley network in the Western Taurus (Turkey): Turkish Journal of Earth Sciences, v. 15, p. 1-23.

Nazik, L., 1992, Beyşehir Gölü Güneybatısı ile Kembos Polyesi Arasının Karst Jeomorfolojisi: İstanbul Üniversitesi, 298 p.

Nazik, L., 1986, Beyşehir Gölü yakın güneyi karst jeomorfolojisi ve karstik parametrelerin incelenmesi: Jeomorfoloji Dergisi, v. 14 , p. 65-77.

Nazik, L., and Poyraz, M., 2017, Türkiye karst jeomorfolojisi genelini karakterize eden bir bölge: Orta Anadolu Platoları karst kuşağı: Türk Coğrafya Dergisi, p. 43-43. https://doi.org/10.17211/tcd.300414.

Nazik, L., and Tuncer, K., 2010, Türkiye karst morfolojisinin bölgesel özellikleri: Türk Speleoloji Dergisi, v. 1, p. 7-19.

Özkale, O., Yetiş, C., and İbilioğlu, D., 2007, Stratigraphy of the Kozlar (Mut-Mersin) area: Çukurova University Journal of the Faculty of Engineering and Architecture, v. 22, p. 261-273.

Öztürk, M.Z., Şener, M.F., Şener, M., and Şimşek, M., 2018, Structural controls on distribution of dolines on Mount Anamas (Taurus Mountains, Turkey): Geomorphology. https://doi.org/10.1016/j.geomorph.2018.05.023.

Öztürk, M.Z., Şimşek, M., Şener, M.F., and Utlu, M., 2018, GIS based analysis of doline density on Taurus Mountains, Turkey: Environmental Earth Sciences. https://doi.org/10.1007/s12665-018-7717-7.

Öztürk, M.Z., Şimşek, M., and Utlu, M., 2015, Tahtalı Dağları (Orta Toroslar) karst platosu üzerinde dolin ve uvala gelişiminin CBS tabanlı analizi: Türk Coğrafya Dergisi, v. 65, p. 59-68. https://doi.org/10.17211/tcd.22648.

Öztürk, M.Z., Şımşek, M., Utlu, M., and Şener, M.F., 2017, Karstic depressions on Bolkar Mountain plateau, Central Taurus (Turkey): Distribution characteristics and tectonic effect on orientation: Turkish Journal of Earth Sciences, v. 26, p. 302-313. https://doi.org/10.3906/yer-1702-3.

Pahernik, M., 2012, Spatial density of dolines in the Croatian Territory: Croatian Geographical Bulletin, v. 74, p. 5-26.

Pardo-Igúzquiza, E., Durán, J.J., and Dowd, P.A., 2013, Automatic detection and delineation of karst terrain depressions and its application in geomorphological mapping and morphometric analysis: Acta Carsologica, v. 42, p. 17-24. http://doi.org/10.3986/ac.v42i1.637.

Parise, M., 2003, Flood history in the karst environment of Castellana-Grotte (Apulia, southern Italy): Natural Hazards and Earth System Science, v. 3, p. 593-604. https://doi.org/ 10.5194/nhess-3-593-2003.

Parise, M., 2011, Surface and subsurface karst geomorphology in the Murge (Apulia, Southern Italy): Acta Carsologica, v. 40, p. 79-93. https:// doi.org/10.3986/ac.v40i1.30.

Parise, M., Pisano, L., and Vennari, C., 2018, Sinkhole clusters after heavy rainstorms: Journal of Cave and Karst Studies, v. 80, p. 83-82.https:// doi.org/10.4311/2017ES0105.

Pepe, M., and Parise, M., 2014, Structural control on development of karst landscape in the Salento Peninsula (Apulia, SE Italy): Acta Carsologica, v. 43, p. 101-114. https://doi.org/10.3986/ac.v43i1.643.

Petrovic, A.S., Calic, J., and Gajovic, V., 2016, Paleodrainage network reconstruction on Miroč Mt. (eastern Serbia): Revista de Geomorfologie, v. 18, p. 59-65.

Plan, L., and Decker, K., 2006, Quantitative karst morphology of the Hochschwab plateau, Eastern Alps, Austria: Zeitschrift für Geomorphologie Supplementband, v. 147, p. 29-54.

Radulović, M.M., 2013, A new view on karst genesis: Carbonates and evaporites, v. 28, p. 383-397.

Reid, C., 1887, On the origin of dry Chalk Valleys and of Coombe Rock: Quarterly Journal of the Geological Society, v. 43, p. 364-373. https:// doi.org/10.1144/GSL.JGS.1887.043.01-04.29.

Robertson, A.H.F., 2000, Mesozoic-Tertiary Tectonic-Sedimentary Evolution of a South Tethyan oceanic basin and its margins in Southern Turkey: Geological Society, London, Special Publications, v. 173, p. 97-138. https://doi.org/10.1144/GSL.SP.2000.173.01.05.

Şafak, Ü., Gökçen, N.S., and Gürbüz, K., 2005, The mid-Cenozoic succession and evolution of the Mut basin, southern Turkey, and its regional significance: Sedimentary Geology, v. 173, p. 121-150. https://doi.org/10.1016/j.sedgeo.2004.03.012.

Sauro, U., 2012, Closed depression in karst area, in White, W. and Culver, D., eds., Encyclopedia of Caves, Academic Press, p. $140-155$.

Sauro, U., 2013, Landforms of mountainous karst in the middle latitudes: reflections, trends and research problems: Acta Carsologica, v. 42, p. 5-16. https://doi.org/10.3986/ac.v42i1.629.

Segura, F.S., Pardo-Pascual, J.E., Rosselló, V.M., Fornós, J., and Gelabert, B., 2007, Morphometric indices as indicators of tectonic, fluvial and karst processes in calcareous drainage basins, South Menorca Island, Spain: Earth Surface Processes and Landforms, v. 32, p. $1928-1946$. https://doi.org/10.1002/esp.1506.

Şenel, M., 2002a, 1/500000 scaled geology map of Turkey, Adana sheet: General Directorate of Mineral Research and Exploration.

Şenel, M., 2002b, 1/500000 scaled geology map of Turkey, Konya sheet: Ankara, Mineral Research and Exploration Institute.

Telbisz, T., Dragušica, D., and Nagy, B., 2009, Doline morphometric analysis and karst morphology of Biokovo Mt (Croatia) based on field observations and digital terrain analysis: Hrvatski Geografski Glasnik, v. 71, p. 5-22.

Warwick, T.G., 1964, Dry valleys of the Southern Pennines, England: Erdkunde, v. 18, p. 116-123. https://doi.org/10.3112/erdkunde.1964.02.07. Williams, P., 1982, Karst landforms in New Zealand, in Soons, J. and Selby, M.J., eds., Landforms of New Zealand, p. 187-209.

Williams, P., 1972, Morphometric analysis of polygonal karst in New Guinea: Geological Society of America Bulletin, v. 83, p. 761-796. https:// doi/10.1130/0016-7606(1972)83[761:MAOPKI]2.0.CO;2. 